\title{
Job Burnout in Front-Line Employees: Moderating Role of Hope and Self-Efficacy
}

\author{
Faiza Akhtar ${ }^{1}$ Dr. Huma Khan ${ }^{2}$
}

\begin{abstract}
The present study investigates the effects of burnout toward job performance and job satisfaction with a moderating role of hope and self-efficacy. Findings from 310 frontline employees of Pakistani commercial bank (Lahore, Karachi \& Islamabad), showed burnout has a significant negative effect on job performance and job satisfaction. A simple random sampling technique was used to collect data, and inferential statistics were applied to analyze the data. However, results disclose no moderation effect of hope on burnout and job performance or with job satisfaction. But, data significantly support the moderation effect of self-efficacy. The moderation effect was analyzed by the moderation process of Preacher, Rucker, \& Hayes, (2007). The study further sheds light on the development of psychological capital, and the importance of the implication of the current finding is discussed. This study will help top management and trainers to understand so they can manage burnout issues on frontline employees for better performance and employee satisfaction.
\end{abstract} Keyswords: Burnout, Psychological capital, Job satisfaction, Job performance, Self-efficacy.

For a secure position in the vicious challenge, an organization must focus on its sustainable competitive advantage in the present dynamic period. The market rivalry has turned into a daily schedule of organizations, and employees should bear the conduction of top-down workload. Job burnout has turned out to be a standard-issue in employees with an increase of market rivalry (Gong, Schooler, Wang, \& Tao, 2018).

In today's world, many changes have occurred in terms of business, culture, diversity, and living standards. A change brings further changes in a related field. After the industrial revolution, many changes in lifestyle, employment, and education took place. From the past 3 to 4 decades, we see that huge businesses are no more dependent on industrial society but also on the service economy. The service industry has expanded and contributes significantly to the GDP of any country. However, such social transformation has its cons and .e.g. psychological pressure to keep up with expectations and profitability. Different kinds of psychological stress have taken place in today's employees. Burnout is one of them; Burnout is a mental stage where one feels emotionally exhausted and detached (Carter, Nesbit, Badham, Parker, \& Sung, 2018). Many Global surveys on the state of the working world have confirmed this experience from different working employees. For example, Gallup research describes, almost 2.7 million Germany based workers were going through burnout effects. 30\% responses of Human resources directors from the United Kingdom survey held in 2013 showed, burnout was common within an organization.

In 1974, Psychologist Herbert Freudenberger initiated the concept of burnout in the research. Where, he described it as a state when one feels emotional depletion and a loss in motivation. Human behavior in 1976 published an article "Burned-Out," by Maslachs. Besides, the process begins. However, most articles and studies are conducted on nurses, hotel employees, physicians, social workers, and teachers. This study wants to take the opportunity to fill the gap of banks' frontline employees, who may encounter it, the most. In the service businesses, the need for profitable business and customer satisfaction is high. Smart and efficient managers have well understood the significance of maintaining their frontline employees in terms of motivation, job satisfaction, and job commitment. These factors are important to the success of a business; likewise, customer satisfaction (Babakus, Yavas, \& Ashill, 2010). The reason behind this aspect is that frontline managers are the most fundamental connection in the arrangement of better management than clients are, and their activities are additionally necessary for benefit recovery when an administration dissatisfaction take place (Yavas, 2007; McLean, Eklund, Kilgus, \& Burns, 2018).

The task is to maintain the balance between clients' expectations of administration excellence and maximize business profitability and performance. Particularly among frontline employees in service sectors, to coop both of these demands can lead to burnout (Zablah, Franke, Brown, \& Bartholomew, 2012). Frontline bank workers frequently experience the ill effects of burnout (Babakus, Yavas, \& Ashill, 2009).

Burnout is a mental reaction to stressors at work (Leiter and Maslach, 2005; Brouwers, \& Tomic, 2016).). Burnout can prompt such unfortunate outcomes such as reduced job performance, job dissatisfaction, moving of time spent on business-related exercises to non-work exercises, lower the organizational commitment, expanded absentees and turnover in the workplace (Shani and Pizam, 2009; Laschinger, Borgogni, Consiglio, \& Read, 2015). Essentially, burnout is infectious, traverses starting with one individual then onto the next, and spreads over the association (Bakker \& Demerouti, 2007).

The long-term impacts of burnout are destructive to the individual experiencing it, for the organization, a particular person with

${ }^{12}$ UCP Business School, Faculty of Management Studies, Lahore. Corresponding author: huma.khan@ucp.edu.pk 
whom burned put person interacts, and the bigger network and surrounding. The job demand resource model suggests that job demands and works pressure result in negative results and job resource; for example, work commitment and work satisfaction diminish adverse effects (Lambert, Qureshi, Frank, Klahm, C \& Smith, 2018).

Front line employees of the banking industry are more inclined to suffer burnout in their job because they played a widespread role in their career, dealing with critical targets of banks and the most important - customer service. Frontline employees need to take into account the satisfaction of customers even though after service failure, dealing with customers, and making them satisfied in the services industry is harder than other job activities. Thus, by this state, they suffer burnout in their job.

The more significant part of the current research on burnout, in any case, has concentrated on situational factors as forerunners of burnout. However, few investigations have tended to the likelihood that identity qualities decisively affect the burnout procedure. However, the current study has underlined the personality traits as potential predecessors of burnout, indicating confidence as the most compelling quality (Alessandri, Perinelli, De Longis, Schaufeli, Theodorou, Borgogni, \& Cinque, 2018). Individual guided intercessions plan to enable employers $s$ to diminish work burnout, typically through showing own adapting aptitudes, unwinding strategies, or methods for expanding social help (Dreison, Luther, Bonfils, Sliter, McGrew, \& Salyers, 2018).

\section{Purpose and study background}

Based on the above-discussed background, the current study is intended to discuss the role of hope and self-efficacy as a moderator between burnout and work satisfaction and performance of employees by using a sample of frontline employees in the private commercial banks of Pakistan.

The current study demonstrates that hope is a core element of psychological capital and an inner resource (Valle et al., 2006; Skaalvik, \& Skaalvik, 2017). Hope can be a remedy to minimize the unfavorable effects of burnout on employee performance and satisfaction. Additionally, self-efficacy is also one of the core elements of psychological capital and has the propensity to cope up with all unfavorable issues and ambiguities. This study prompts to investigate the role of hope and self-efficacy within the context of job satisfaction and performance.

By looking at the purpose of the study, it can be deduced that the current study is an attempt to examine that both self-efficacy and hope act as personal resources, moderate the effect of job burnout and job satisfaction, and job performance. To the best of our understanding, studies have rarely investigated this comprehensive framework on frontline employees in commercial banks of Pakistan.

Burnout is defined in different ways e.g., Emotional Exhaustion, Depersonalization, and lack of individual achievements. Emotional exhaustion has known to be a sensitivity of tiredness and sickness that occur due to a lack of self- confidence and diversion. Depersonalization is defined, as a state when an individual acts as different from his or her individuality (Michal, Duven, Giralt, Dreier, Müller, Adler, \& Wölfling, 2015).
The newly stimulated attention plays a vital role in the field of organizational behavior and giving importance to the performance of employees, which is defined as strengths and in terms of positive character. Researchers have now aligned and understood the effects of an individual's self-esteem and self-efficacy, interior locus of control, and emotional stability on employees' performance (Kozak, 2014). Big five as conscientiousness is also aligned with performance (Judge, \& Zapata, 2015).

Researchers have discussed the importance of positive psychology on high job performance. However, studies on how different psychological effects can minimize burnout are still disregarded. The analysis of this study will attempt to explain the impact of positive psychological outcomes (Hope and Self-effect) on job performance, job satisfaction, and job commitment, particularly on the frontline employees working for the banks. Positive mental states are newly called positive organizational behavior (POB) and are highly dependent on this (Luthans, 2002a, 2002b, 2003; Luthans, Youssef-Morgan, \& Avolio, 2015) and different terms including such as desire, confidence, and flexibility (Luthans and Youssef, 2004). In other contexts, culture is defined in terms of organizational behavior (Adler \& Gundersen, 2002). This article's justification is to explain positive psychological states with the help of gathering data related to a sample of banking frontline and middle-level employees in the workplace. In mainly, we analyzed the relationship between bank employee's positive psychological states (expectation, good faith, and versatility) and their performance and satisfaction, including data gathered $(n=310)$ of bank employees.

In the terms of psychology, trait-like personality constructs are defined as relatively fixed, based on the conditional term of relative capacities (Allen and Potkay, 1981). To date, there has been irregularity considering looking at the part that individual positive psychological states, such as trust (e.g., Peterson and Luthans, 2003) or good faith (e.g., Seligman, 1998a) as a mediator on burnout and workers' execution, job satisfaction. There has been original research on the part that general mental capital can play in decreasing power burnout toward employee performance and comfort (Jiang, \& Tian, 2018). Besides, this study describes the examination of the structure on the frontline and middle-level employees of private banks.

Psychological capital is a sturdy construct, which contributes to the advancement of positive organizational psychology research. Psychological capital is a mental quality that enhances the execution of work and safeguards the adverse outcomes at the workplace (Abbas \& Raja, 2015). In 2015, Bitmis and Ergeneli conducted research on nurses and stated that psychological capital negatively influences the burnout at work; further, they explained the role of job insecurity, created a significant linkage between psychological capital and burnout. Also, as underlined by Bandura (2006), self-efficacy should not be considered a common attribute, and explicit self-efficacy measures ought to be utilized in connection to the object of intrigue (Fida, Laschinger, \& Leiter, 2018).

Recently, a study has been conducted on nurses, which shows the consequences of burnout not only at the workplace, even though burnout affects individual mental health. The importance of 
psychological capital as a useful tool for creating a favorable environment at the workplace is highlighted (Estiri, Nargesian, Dastpish, \& Sharifi, 2016). Most of the studies on job burnout and psychological capital has been inculcated the sample of nurses. However, this study incorporates a comprehensive framework on the banking employee, as banking sector employees usually don't get enough time to understand their self-relaxed and to wind down in the phase of stress, anxiety, and workload and at conflicting situations (Dhankar, 2015).

The study proposes a hypothesis from the above discussion.

\section{Hypothesis}

H1: Job burnout has negative relationship with job performance

H2: Job burnout has negative relationship with job satisfaction

H3a: Hope moderates the relationship between job burnout and job performance

H3b: Hope moderates the relationship between job burnout and job satisfaction

H4a: Self-efficacy moderates the relationship between job burnout and job performance

H4b: Self-efficacy moderates the relationship between job burnout and job satisfaction.

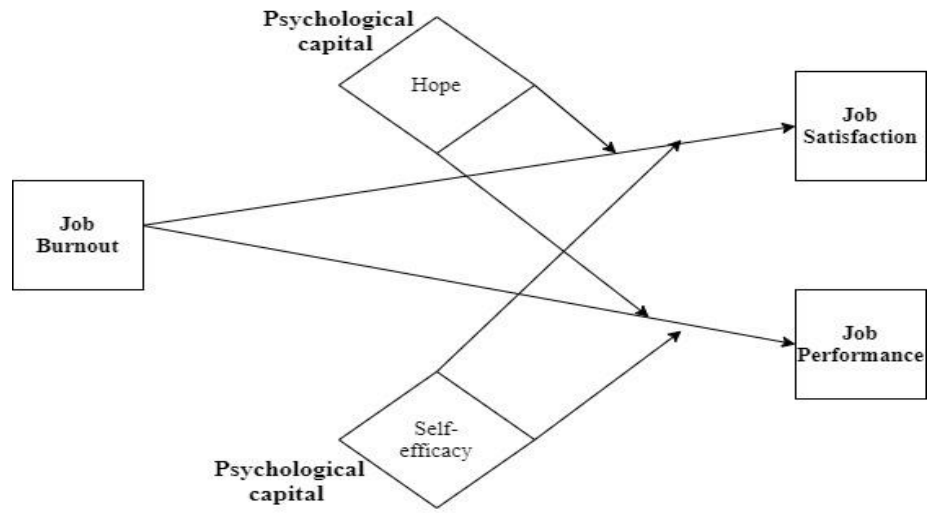

Figure 1: Effect of Burnout on Job Satisfaction and performance: A conceptual framework

\section{Methodology and Data Analysis}

The given study tests the burnout of frontline employees on job satisfaction and job, along with the moderating role of selfefficacy and hope. This study is a comprehensive positivism approach because it is scientific and gives more objectivity (Bryman and Bell, 2015). This investigation is cross-sectional base examinations directed at just a single interim of time. The survey method was used to assemble information. The study utilizes a sample of 310 employees from different private banks (Albaraka Bank, United Bank, Askari Bank, Limited, Faysal Bank, Standard Chartered, \&Bank Alfalah) by simple random sampling technique. The current study used a simple random sampling strategy for the collection of data, sampling size was determined by Tabachnick \& Fidell, (2007) sampling formula.

\section{Measures}

\section{Job burnout}

In 1998, Demerouti, Bakker, Nachreiner, and Schaufeli (2001) presented the Oldenburg Burnout Inventory; this measure is used to measure burnout in this paper with a total of 16 items.
Respondents answered on 4 Likert scales 1 strongly agree to 4 strongly disagree. Further, this scale consists of two dimensions. These are exhaustion and disengagement, both comprised of eight items, respectively. The reliability of this scale is (0.774).

Job Performance

Employees' performance is measured using Williams and Anderson's (1991) scale, of in-role behaviors, which consist of 9 items on a scale with 5 Likert scale points. The reliability of this scale is (.83).

Job satisfaction

The satisfaction of employees, measured by using Agho, Price, and Mueller (1992) scale, consists of 6 items in it with a 5 Likert scale. The reliability of job satisfaction is (0.791).

Hope and self-efficacy:

Hope and self-efficacy were adopted from Luthan, Yousef \& Avolio (2007), a scale of psychological capital, 06 item scale with a 5-point Likert scale, 1 strongly disagree through 5 strongly agree. Each construct consists of three items, respectively. The reliability of hope and self-efficacy is (0.696 and 0.753), respectively.

\section{Results}

Male respondents were 201(64.83), and female respondents were $109(35.16 \%)$, from a total of 310 respondents. The qualification of respondents is that most employees have a master's qualification $50.96 \%(\mathrm{n}=158)$, graduates are $37.74 \%(\mathrm{n}=117)$ and MPhil/Ph.D.'s are $11.29 \%(n=35)$. The mean age of the respondents is 30.74 , ranges from 20 to 53

Correlation analysis express the variables related to the level of significance. Therefore, the relationship between the burnout and job performance is $r=-0.454 * *$. This shows a significant negative correlation between burnout and job performance as the p-value is less than 5\%. The relationship between the burnout and job satisfaction is $r=-0.501^{*}$, which shows a significant negative relationship as the p-value is less than 5\%. The relationship between the burnout and hope is $\mathrm{r}=-0.192 *$. This shows a significant negative relationship as the p-value is less than $5 \%$.

The relationship between burnout and self-efficacy is also negative $r=-0.217$. The study found significant support for the hypotheses in the relationship aspect as predicted. As hope and self-efficacy are the moderators in the current framework, correlation can analyze the direction of the relation of hope and self-efficacy with other variables.

Table 1: Correlation Analysis

\begin{tabular}{|c|c|c|c|c|c|}
\hline & $\begin{array}{c}\text { Job } \\
\text { Burnout }\end{array}$ & $\begin{array}{c}\text { Job } \\
\text { Performance }\end{array}$ & $\begin{array}{c}\text { Job } \\
\text { Satisfaction }\end{array}$ & Hope & $\begin{array}{c}\text { Self- } \\
\text { Efficacy }\end{array}$ \\
\hline Job Burnout & 1 & & & & \\
\hline Job & $-0.454 * *$ & 1 & & & \\
\hline Performance & & & & & \\
\hline Job Satisfaction & $-0.501 *$ & $0.310 *$ & 1 & & \\
\hline Hope & $-0.192 *$ & $0.208 *$ & 0.105 & 1 & \\
\hline Self-Efficacy & $-0.217 *$ & $0.327 *$ & $0.201 *$ & $0.377 *$ & 1 \\
\hline
\end{tabular}

Regression analysis uses to determine the variance among variables. A linear regression model runs to investigate the variance between job burnout on job satisfaction and job performance. The study utilized a sample of 310 employees through SPSS.

The study hypothesizes first that job burnout has a negative relationship with job performance. Regression investigation represents that job burnout style has a negative impact on job 
performance $\left(\beta=-0.561^{* *}, \mathrm{p}<0.00\right)$, and the $\mathrm{r}$ square shows a $37.1 \%$ variance in job performance because of burnout. Thus, H1 is accepted. Furthermore, the study's Second hypothesizes that job burnout has a negative impact on job satisfaction, the regression analysis depicts that job burnout style has a negative effect on job satisfaction $\left(\beta=-0.587^{*}, \mathrm{p}<0.05\right)$ and the $\mathrm{r}$ square shows $29.9 \%$ variance in job satisfaction because of job burnout. Therefore, H2 is accepted.

Table 2: Regression Analysis

\begin{tabular}{lllll}
\hline & \multicolumn{2}{c}{ Job Performance } & \multicolumn{2}{c}{ Job Satisfaction } \\
& $\begin{array}{l}\text { Unstandardized } \\
\text { Beta }\end{array}$ & $\begin{array}{l}\text { Change } \\
\text { in } \boldsymbol{R}^{\mathbf{2}}\end{array}$ & $\begin{array}{l}\text { Unstandardized } \\
\text { Beta }\end{array}$ & $\begin{array}{l}\text { Change } \\
\text { in } \boldsymbol{R}^{\mathbf{2}}\end{array}$ \\
\hline Gender & $0.212^{*}$ & $0.029^{*}$ & $0.192^{*}$ & $0.016^{*}$ \\
Age & -0.010 & 0.001 & -0.007 & 0.000 \\
Qualification & 0.067 & $0.010^{*}$ & 0.048 & 0.022 \\
Job Burnout & $-0.561^{* *}$ & $0.371^{*}$ & $-0.587^{*}$ & $0.299^{*}$ \\
\hline
\end{tabular}

Table 3 demonstrates that Hope and self-efficacy act as a moderator in the relationship between job burnout toward job performance and job satisfaction. For moderation regression, an interactive term was used to check the effect (Raja, Johns \& Ntalianis, 2004) of Hope and self-efficacy with job burnout. In 2007, Preacher, Rucker, \& Hayes presented a technique to test the moderation; current research also used that technique to test the moderation the effect.

The process moderation results are given below; the combined effect of job burnout and Hope is $(\beta=-0.2001, p>.05)$, indicating the interactive term has an insignificant impact on job performance. Thus, analysis shows data do not support h3a. For the $\mathrm{H} 3 \mathrm{~b}$, the combined effect of job burnout and Hope is $(\beta=-$ $0.262 \mathrm{p}>.05)$, which is indicating that the interactive term has an insignificant impact on job satisfaction. Thus, analysis shows data do not support h3b, Hope does not moderate the relationship between job burnout and job satisfaction in front line employees. The combined effect of job burnout and self-efficacy is $(\beta=$ $.0 .189 *, \mathrm{p}<.05)$, which is indicating the interactive term has a significant impact on job performance. Additionally, the study can observe the change in $\mathrm{R}$ Square. The value of change in $\mathrm{R}$ square has moved from $37.1 \%$ to $40.2 \%$. This term explains the variation in mode. Thus, analysis shows $\mathrm{H} 4 \mathrm{a}$ is accepted. The combined effect of job burnout and self-efficacy is $\left(\beta=-0.217^{*}, p<.05\right)$, indicating the interactive term has a significant impact on job satisfaction.

Furthermore, the study can observe the change in R Square, and the value of change in $\mathrm{R}$ square has moved from $29.9 \%$ to $34.3 \%$. This term explains the variation in mode. Thus, analysis shows $\mathrm{H} 4 \mathrm{~b}$ is accepted.

Table 3: Moderation Effect

\begin{tabular}{lcc}
\hline & Job Performance & Job Satisfaction \\
\hline Job Burnout & -0.384 & -0.283 \\
Hope & $0.401^{*}$ & $0.397^{*}$ \\
Job Burnout * Hope & -0.200 & -0.262 \\
Job Burnout & -0.275 & $-0.198^{*}$ \\
Self-Efficacy & $0.196^{*}$ & $0.205^{*}$ \\
Job Burnout* Self-Efficacy & $-0.189^{*}$ & $-0.217^{*}$ \\
\hline
\end{tabular}

\section{Discussion}

The current study motive was to determine the effect of job burnout on job performance and job satisfaction with the moderating role of hope and self-efficacy on front line employees of private commercial banks in Pakistan. Data were collected from major cities of Pakistan (Lahore, Karachi, and Islamabad). The sample size of 310 employees from different banks demonstrates that job burnout has a significant negative association with job performance and job satisfaction. Preacher, Rucker, and Hayes (2007) technique was used for the moderation effect. Results show that self-efficacy moderates the relationship between job burnout toward job performance and job satisfaction, respectively. However, hope does not moderate the relationship between job burnout toward job performance and job satisfaction, respectively. The study's outcomes were consistent with Bakker, Demerouti, \& Verbeke, (2004) that job burnout is associated with the other role and in-role performance on employees. Moreover, another stance in the study is the moderation effect of hope and self-efficacy; the results show the self-efficacy support. Self-efficacy helps individuals fight from uncertain issues at work and reduces the impact of tension and exhaustion at work (Abbas \& Raja, 2015). This can lead to enhance performance at the workplace. From the theoretical standpoint, this framework has been investigated rarely in Pakistan with frontline employees at the bank. However, the study hopes to contribute to the theoretical framework where psychological capital could be enhanced to reduce the stress, burnout, tension, and related factor at the workplace (Wang, Sui, Luthans, Wang \& Wu, 2014).

Hence, discrepancies remain present in the literature regarding the psychological capital of employees. Moreover, frontline employees usually are the ones who suffer by negative behavior of job due to work nature, pressure, and cultural factors influence this perception. Psychological capital is a mental state of an individual can be a safeguard to unfavorable issues or behavior at the workplace (Masud, Thurasamy, \& Ahmad, 2015). This study investigates with the given sample that such self-efficacy allows one mind to strive with burnout conditions so burnout couldn't affect performance and job satisfaction. Moreover, burnout's findings have a negative association with the performance and satisfaction and the productive role of self-efficacy. The current study also provides the insight that psychological capital (hope, self-efficacy, resilience, and optimism) is open to development. It should be incorporated by organizations to gain a competitive edge in the human development field (Peterson, Luthans, Avolio, Walumbwa, \& Zhang, 2011).

\section{Limitation}

Although the study contains a wealth of information regarding burnout and psychological capital to researchers and audiences, research also has few limitations. The first limitation is the use of an existing scale; a new scale may result in a better result. The second limitation is this study is a cross-sectional, longitudinal Study that may yield better outcomes. The third limitation is the small sample size. Future studies need to encounter a larger sample to generalize this study. The significant limitation is the use of a single methodology strategy. Exploratory Study or mixed-method Study could be beneficial in terms of results understanding.

\section{Practical Implication and Future Recommendation}

The current study has attempted to highlight the impact of burnout on frontline employees of banks. Burnout has already been 
discussed in the literature. However, previously this concept mostly tested in the domain of teachers, nurses, or consultant perspective and rarely on bank employees. The study also endorses the idea that burnout needs to be exposures further, and real strategies are required by managers to overcome burnout. Future researchers are highly advices to work on burnout with different models and techniques. For example, with emotional intelligence. Emotional intelligence can be a source to fight and overcome burnout, especially in the service sector. An employee is expected to treat the clients well for his own better hearth conditionals and job performance. For the future, research mixed could be beneficial and might give in-depth results. As the behavioral sciences field may yield better results in the qualitative approach. This study will help top management and trainer to understand and minimize burnout issues in frontline employees for better performance and satisfaction in employees. This study will also help trainers and practitioners understand how increasing and improving psychological capital will help employees perform better in uncertain situations.

\section{References}

Abbas, M., \& Raja, U. (2015). Impact of psychological capital on innovative performance and job stress. Canadian Journal of Administrative Sciences/Revue Canadienne des Sciences de l'Administration, 32(2), 128-138.

Adler, N. J., \& Gundersen, A. (2007). International dimensions of organizational behavior. Cengage Learning.

Agho, A. O., Price, J. L., \& Mueller, C. W. (1992). Discriminant validity of measures of job satisfaction, positive affectivity and negative affectivity. Journal of Occupational and Organizational Psychology, 65(3), 185-195.

Alessandri, G., Perinelli, E., De Longis, E., Schaufeli, W. B., Theodorou, A., Borgogni, L., \& Cinque, L. (2018). Job burnout: The contribution of emotional stability and emotional selfefficacy beliefs. Journal of Occupational and Organizational Psychology, 91(4), 823-851.

Allen, B. P., \& Potkay, C. R. (1981). On the arbitrary distinction between states and traits. Journal of Personality and Social Psychology, 41(5), 916.

Babakus, E., Yavas, U., \& Ashill, N. J. (2009). The role of customer orientation as a moderator of the job demandburnout-performance relationship: A surface-level trait perspective. Journal of Retailing, 85(4), 480-492.

Babakus, E., Yavas, U., \& Ashill, N. J. (2010). Service worker burnout and turnover intentions: Roles of person-job fit, servant leadership, and customer orientation. Services Marketing Quarterly, 32(1), 17-31.

Bakker, A. B., Demerouti, E., \& Verbeke, W. (2004). Using the job demands-resources model to predict burnout and performance. Human Resource Management, 43(1), 83-104.

Bakker, A. B., \& Demerouti, E. (2007). The job demandsresources model: State of the art. Journal of Managerial Psychology, 22(3), 309-328.

Bitmiş, M. G., \& Ergeneli, A. (2015). How psychological capital influences burnout: the mediating role of job insecurity. Procedia-Social and Behavioral Sciences, 207(1), 363-368.
Brouwers, A., \& Tomic, W. (2016). Job-demands, job control, social support, self-efficacy, and burnout of staff of residential children's homes. Educational Practice and Theory, 38(1), 89107.

Bryman, A., \& Bell, E. (2015). Business research methods. Oxford University Press, USA.

Carter, W. R., Nesbit, P. L., Badham, R. J., Parker, S. K., \& Sung, L. K. (2018). The effects of employee engagement and selfefficacy on job performance: a longitudinal field study. The International Journal of Human Resource Management, 29(17), 2483-2502.

Chan, K.W. and Wan, E.W. (2012), "How can stressed employees deliver better customer service? The underlying self-regulation depletion mechanism", Journal of Marketing, 76(1), 119-37.

Deery, M. (2008). Talent management, work-life balance and retention strategies. International Journal of Contemporary Hospitality Management, 20(7), 792-806.

Demerouti, E., Bakker, A.B., Nachreiner, F. and Schaufeli, W.B. (2001), "The job demands resources model of burnout", Journal of Applied Psychology, 86(3) ,499-512.

Dhankar, S. (2015). Occupational stress in banking sector. International Journal of Applied Research, 1(8), 132135.

Dreison, K. C., Luther, L., Bonfils, K. A., Sliter, M. T., McGrew, J. H., \& Salyers, M. P. (2018). Job burnout in mental health providers: A meta-analysis of 35 years of intervention research. Journal of Occupational Health Psychology, 23(1), 18.

Estiri, M., Nargesian, A., Dastpish, F., \& Sharifi, S. M. (2016). The impact of psychological capital on mental health among Iranian nurses: considering the mediating role of job burnout. SpringerPlus, 5(1), 13-77.

Fernet, C., Chanal, J., \& Guay, F. (2017). What fuels the fire: jobor task-specific motivation (or both)? On the hierarchical and multidimensional nature of teacher motivation in relation to job burnout. Work \& Stress, 31(2), 145-163.

Fida, R., Laschinger, H. K. S., \& Leiter, M. P. (2018). The protective role of self-efficacy against workplace incivility and burnout in nursing: A time-lagged study. Health Care Management Review, 43(1), 21-29.

Gong, Z., Schooler, J. W., Wang, Y., \& Tao, M. (2018). Research on the relationship between positive emotions, psychological capital and job burnout in enterprises' employees: based on the broaden-and-build theory of positive emotions. Canadian Social Science, 14(5), 42-48.

Jiang, J., \& Tian, F. (2018). Mediating role of positive psychological capital in relationship between professional identity and learning burnout in higher vocational nursing students. Chinese Journal of Behavioral Medicine and Brain Science, 27(9), 839-842.

Judge, T. A., \& Zapata, C. P. (2015). The person-situation debate revisited: Effect of situation strength and trait activation on the validity of the big five personality traits in predicting job performance. Academy of Management Journal, 58(4), 11491179. 
Kozak, A. (2014). Relationship between job satisfaction and perception of manager's behavior. Journal for Perspectives of Economic Political and Social Integration, 20(1-2), 37-52.

Lambert, E. G., Qureshi, H., Frank, J., Klahm, C., \& Smith, B. (2018). Job stress, job involvement, job satisfaction, and organizational commitment and their associations with job burnout among Indian police officers: a research note. Journal of Police and Criminal Psychology, 33(2), 85-99.

Laschinger, H. K. S., Borgogni, L., Consiglio, C., \& Read, E. (2015). The effects of authentic leadership, six areas of work life, and occupational coping self-efficacy on new graduate nurses' burnout and mental health: A cross-sectional study. International Journal of Nursing Studies, 52(6), 1080-1089.

Leiter, M. P., \& Maslach, C. (2005). Banishing burnout: Six strategies for improving your relationship with work. John Wiley \& Sons.

Luthans, F. (2002a). Positive organizational behavior: developing and maintaining psychological strengths. Academy of Management Executive, 16, 57-72.

Luthans, F. (2002b). The need for and meaning of positive organizational behavior. Journal of Organizational Behavior, 23, 695-706.

Luthans, F., Avey, J. B., Avolio, B. J., Norman, S. M., \& Combs, G. M. (2006). Psychological capital development: toward a micro-intervention. Journal of Organizational Behavior, 27(3), 387-393.

Luthans, F., \& Youssef, C. M. (2004). Human, social, and now positive psychological capital management: Investing in people for competitive advantage. Organizational Dynamics, 33(2), 143-160.

Luthans, F., Youssef, C. M., \& Avolio, B. J. (2007). Psychological capital: Developing the human competitive edge (p. 3). Oxford: Oxford University Press.

Luthans, F., Youssef-Morgan, C. M., \& Avolio, B. J. (2015). Psychological capital and beyond. Oxford University Press, USA.

Masud, H., Thurasamy, R., \& Ahmad, M. S. (2015). Parenting styles and academic achievement of young adolescents: A systematic literature review. Quality \& Quantity, 49(6), 24112433.

McLean, D., Eklund, K., Kilgus, S. P., \& Burns, M. K. (2018). Influence of teacher burnout and self-efficacy on teacher-related variance in social-emotional and behavioral screening scores. School Psychology Quarterly.

Michal, M., Duven, E., Giralt, S., Dreier, M., Müller, K. W., Adler, J., .. \& Wölfling, K. (2015). Prevalence and correlates of depersonalization in students aged 12-18 years in Germany. Social Psychiatry and Psychiatric Epidemiology, 50(6), 9951003.

Peterson, S. J., Luthans, F., Avolio, B. J., Walumbwa, F. O., \& Zhang, Z. (2011). Psychological capital and employee performance: A latent growth modeling approach. Personnel Psychology, 64(2), 427-450.

Preacher, K. J., Rucker, D. D., \& Hayes, A. F. (2007). Addressing moderated mediation hypotheses: Theory, methods, and prescriptions. Multivariate Behavioral Research,42(1), 185227.

Peterson, S. J., \& Luthans, F. (2003). The positive impact and development of hopeful leaders. Leadership \& Organization Development Journal, 24(1), 26-31.

Raja, U., Johns, G., \& Ntalianis, F. (2004). The impact of personality on psychological contracts. Academy of Management Journal, 47(3), 350-367.

Seligman, M. E. (1998). What is the good life? APA monitor, 29(10), 2.

Shani, A., \& Pizam, A. (2009). Work-related depression among hotel employees. Cornell Hospitality Quarterly, 50(4), 446-459.

Skaalvik, E. M., \& Skaalvik, S. (2017). Motivated for teaching? Associations with school goal structure, teacher self-efficacy, job satisfaction and emotional exhaustion. Teaching and Teacher Education, 67, 152-160.

Tabachnick, B. G., \& Fidell, L. S. (2007). Experimental designs using ANOVA. Thomson/Brooks/Cole.

Valle, M.F., Huebner, E.S. and Suldo, S.M. (2006), "An analysis of hope as a psychological strength", Journal of School Psychology, 44(5), 393-406.

Wang, H., Sui, Y., Luthans, F., Wang, D., \& Wu, Y. (2014). Impact of authentic leadership on performance: Role of followers' positive psychological capital and relational processes. Journal of Organizational Behavior, 35(1), 5-21.

Williams, L. J., \& Anderson, S. E. (1991). Job satisfaction and organizational commitment as predictors of organizational citizenship and in-role behaviors. Journal of Management, 17(3), 601-617.

Zablah, A. R., Franke, G. R., Brown, T. J., \& Bartholomew, D. E. (2012). How and when does customer orientation influence frontline employee job outcomes? A meta-analytic evaluation. Journal of Marketing, 76(3), 21-40. 